\title{
Hepatit B'ye bağlı siroz hastalarında hepatosellüler karsinom gelişiminde prediktif faktörlerin incelenmesi
}

\author{
Investigation of predictive factors for hepatocellular carcinoma development in patients with chronic \\ hepatitis B-induced cirrhosis
}

\author{
(D) Alihan ORAL' ${ }^{1}$ (DTolga ŞAHIN² \\ Demiroğlu Bilim Üniversitesi, Tıp Fakültesi, 'İç Hastalıkları Anabilim Dalı, ${ }^{1}$ Gastroenteroloji Bilim Dalı, İstanbul
}

\begin{abstract}
Giriș ve Amaç: Bu çalışmanın amacı kronik hepatit B'ye bağlı siroz hastalarında, hepatosellüler karsinom gelişimini etkileyen faktörlerin değerlendirilmesidir. Gereç ve Yöntem: Ocak 2010 - Ocak 2019 yılları arasında Demiroğlu Bilim Üniversitesi Tıp Fakültesi gastroenteroloji polikliniğinde hepatit B virüsüne bağlı karaciğer sirozu nedeniyle takip edilen 18 yaş üstü 324 hasta çalışmaya dahil edildi. Olguların demografik (yaş, cinsiyet), beden kitle indeksi, laboratuvar [biyokimyasal ve serolojik parametreler (hepatit B yüzey antijeni, hepatit b virüs-DNA)], görüntüleme ve biyopsi sonuçları hastane bilgi sisteminden retrospektif olarak toplandı. Hastalar hepatosellüler karsinom ve non- hepatosellüler karsinom olarak iki gruba ayrıldı. Bulgular: Çalışmaya dahil edilen hastaların 114'ü hepatosellüler karsinom ve 210'u ise non- hepatosellüler karsi-

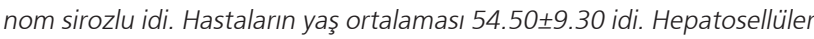
karsinom ile non-hepatosellüler karsinom grupları karşılaştıııldı̆ında yaş ortalaması, Homeostatic Model of Assessment Insulin Resistance, hepatit $B$ virüs-DNA ve alfa fetoprotein değerleri hepatosellüler karsinom grubunda istatistiksel olarak daha yüksek saptandı. Asit, özofagus varis kanaması ve hepatik ensefalopati non-hepatosellüler karsinom grubunda daha yüksek oranda görülürken, spontan bakterivel peritonit ise hepatosellüler karsinom grubunda istatistiksel olarak daha yüksek oranda bulundu. Hepatosellüler karsinom oluşumunu öngörebilecek bağımsız risk faktörleri incelendiğinde, alfa fetoprotein ve hepatit $B$ virüs-DNA değerlerinin istatistiksel olarak bağımsız risk faktörü olduğu görüldü (sIrasılyla; $p=0.001$ ve $p=0.037$ ). Sonuç: Çalışmamızda hepatit $B$ virüsüne bağlı siroz hastalarında hepatosellüler karsinom için alfa fetoprotein ve hepatit B virüs-DNA değerleri bağımsız risk faktörü olarak saptandı. Alfa fetoprotein ve hepatit $B$ virüs-DNA değerleri hepatit $B$ virüsüne bağl siroz hastalarında hepatosellüler karsinom gelişiminde kullanışlı birer belirteç olabilir.
\end{abstract}

Anahtar kelimeler: Hepatit B, HBV, siroz, hepatosellüler karsinom
Background and Aims: This study aimed to investigate the factors affecting the development of hepatocellular carcinoma in patients with chronic hepatitis B-induced cirrhosis. Materials and Methods: In total, 324 patients of $>18$ years of age, who were followed up with the diagnosis of chronic hepatitis B-induced cirrhosis in the gastroenterology outpatient clinic of Demiroglu Bilim University between January 2010 and January 2019, were included in this study. Demographic details (age, gender, body mass index), laboratory (biochemical and serological tests, such as hepatitis $B$ virus surface antigen and hepatitis $B$ virus DNA) test results, radiological imaging, and liver biopsy findings were retrospectively scanned and recorded from the hospital's central information system. The patients were divided into two groups: hepatocellular carcinoma cirrhosis and non-hepatocellular carcinoma cirrhosis group. Results: In total, 114 patients of this study were assigned to the hepatocellular carcinoma group, whereas 210 patients were assigned to the non-hepatocellular carcinoma cirrhosis group. The mean age of patients in this study was $54.50 \pm 9.30$ years. When hepatocellular carcinoma and non-hepatocellular carcinoma groups were compared, mean age, homeostatic model of assessment insulin resistance, and the values of hepatitis B virus DNA and alpha-fetoprotein were significantly higher in the hepatocellular carcinoma group. Ascites, esophageal variceal hemorrhage, and hepatic encephalopathy were higher in the non-hepatocellular carcinoma cirrhosis group, whereas spontaneous bacterial peritonitis was higher in the hepatocellular carcinoma group. Alpha-fetoprotein and hepatitis $B$ virus DNA values were found to be statistically independent risk factors ( $p=0.001$ and $p=0.037$, respectively). Conclusion: Alpha-fetoprotein and hepatitis $B$ virus DNA values were detected as the independent risk factors in patients with chronic hepatitis B-induced cirrhosis in this study. Therefore, alpha-fetoprotein and hepatitis $B$ virus DNA can be useful markers for hepatocellular carcinoma development in these patients.

Keywords: Hepatitis B, HBV, cirrhosis, hepatocellular carcinoma

fetoprotein (AFP) ve siroz gibi faktörler HCC için prediktif faktörler olarak bulunmuştur (6). HBV, HCC'nin en önemli nedenlerinden biridir ve dünyada birçok ölüme sebep olmaktadır (7). Akut enfeksiyondan altı ay sonra hepatit B yüzey antijeni (HBsAg) pozitifliğinin devam etmesi kronik enfeksiyon olarak değerlendirilmektedir (8). HCC'lilerin $\% 50$ 'den fazlası HBV ile ilişkilidir $(9,10)$. HBV ile HCC ilişkisini etkileyen faktörler, ilgili birçok çalışma yapılmasına 
rağmen hala net anlaşılamamıştır (11-13). Bu nedenle bu çalışmada HBV'ye bağlı siroz hastalarında HCC gelişimini etkileyen faktörleri değerlendirmeyi amaçladık.

\section{GEREÇ ve YÖNTEM}

Araştırmaya 01.01.2010-01.01.2019 yılları arasında Demiroğlu Bilim Üniversitesi Tıp Fakültesi gastroenteroloji polikliniğinde HBV'ye bağlı karaciğer sirozu nedeniyle takip edilen 18 yaş üstü 324 hasta dahil edildi. Etik kurul onayı Demiroğlu Bilim Üniversitesi Etik Kurulu tarafından verildi ve Helsinki Bildirgesi'ne uyuldu (Karar tarih: 06.08.2019, Karar no: 2019-16-03). Olguların demografik (yaş, cinsiyet, boy, kilo), beden kitle indeksi (BMI), laboratuvar [biyokimyasal ve serolojik parametreler (HBsAg, HBV-DNA)], görüntüleme ve biyopsi sonuçları hastane bilgi sisteminden ve dosyalarından retrospektif olarak toplandı. Hastaların ayrıca insülin direnci Homeostatic Model of Assessment (HOMA-IR) (22.5 x açlık insulin $[\mathrm{mU} / \mathrm{mL}] \times$ glukoz $[\mathrm{mmol} / \mathrm{L}])$ olarak hesaplandı. Hastalar HCC ve non-HCC olarak iki gruba ayrıldı. HCC tanısı karaciğer biyopsisi ile konulmuş̧tu.

Çalışma dışında bırakılma kriterleri; 18 yaşından küçük olan, tetkik bakılmayan veya bilinmeyen hastalar, aktif enfeksiyonu olanlar, HBV ile beraber HDV veya HCV enfeksiyonu olan hastalar, alkol ve sigara kullanan hastalar, HBV dışında kronik karaciğer hastalı̆̆ı olanlar idi.
Istatiksel analiz olarak; sayısal veriler ortalama-standart sapma olarak verilmiştir. Normal dağılım gösteren veriler student-t test ile; normal dağılım göstermeyen veriler ise Mann-Whitney $U$ testi ile hesaplandı. Kategorik veriler ise Chi-kare ile hesaplandı. Bağımsız risk faktörü için lojistik regresyon analizi kullanıldı. İstatiksel analiz SPSS-21 programı ile yapılarak $\mathrm{Cl} \% 95$ ve $\mathrm{P} \mathrm{Cl} \% 95$ ve $\mathrm{P}<0.05$ anlamlı olarak kabul edildi.

\section{BULGULAR}

Çalışmaya dahil edilen hastaların $114^{\prime} u ̈$ HCC ve $210^{\prime} u$ ise non-HCC idi. Hastaların yaş ortalaması $54.50 \pm 9.30$ ve \%74.8'i erkek, \%25.2'si kadındı. HCC ile non-HCC grupları karşılaştırıldığında cinsiyet, beden kitle endeksi (BMI), alanin aminotransferaz (ALT), alkalen fosfotaz (ALP) ve HBsAg pozitifliği benzerdi. Yaş ortalaması, gama glutamil transferaz (GGT), albümin, trigliserit, total kolesterol, HOMA-IR, HBV-DNA ve AFP değerleri HCC grubunda istatistiksel olarak daha yüksek saptanırken aspartat aminotransferaz (AST) ve total bilüribin değerleri ise non-HCC grubunda daha yüksek saptandı (Tablo 1).

Siroz komplikasyonlarının HCC ve non-HCC gruplarındaki oranları Tablo 2'de gösterilmiştir. Asit, özofagus varis kanaması ve hepatik ensefalopati non-HCC grubunda daha yüksek oranda görülürken spontan bakteriyel peritonit ise istatistiksel olarak HCC grubunda daha yüksek bulundu.

Tablo 1. HCC grubu ile non-HCC grubunun klinik, laboratuvar ve demografik özelliklerinin karşılaştırılması

\begin{tabular}{|c|c|c|c|}
\hline & $\mathrm{HCC}(n=114)$ & Non-HCC $(n=210)$ & $\mathbf{P}^{*}$ \\
\hline Yaş & $54.62 \pm 7.61$ & $49.54 \pm 9.49$ & $<0.001$ \\
\hline Cinsiyet (kadın/erkek, n) & $22 / 92$ & $56 / 154$ & $0.88^{* *}$ \\
\hline Beden kitle indeksi $\left(\mathrm{kg} / \mathrm{m}^{2}\right)$ & $27.30 \pm 3.78$ & $26.03 \pm 3.88$ & 0.36 \\
\hline ALT (IU/L) & $65.82 \pm 48.60$ & $64.47 \pm 60.89$ & 0.31 \\
\hline AST (IU/L) & $80.01 \pm 63.93$ & $95.20 \pm 76.30$ & 0.009 \\
\hline $\operatorname{ALP}(U / L)$ & $160.26 \pm 136.06$ & $155.77 \pm 89.86$ & 0.666 \\
\hline GGT (U/L) & $138.95 \pm 198.09$ & $79.52 \pm 90.02$ & $<0.001$ \\
\hline Total bilüribin (mg/dl) & $2.27 \pm 2.85$ & $5.86 \pm 8.17$ & $<0.001$ \\
\hline Albümin (g/dl) & $3.54 \pm 0.75$ & $2.92 \pm 0.57$ & $<0.001$ \\
\hline Trigliserit (mg/dL) & $92.41 \pm 42.44$ & $75.73 \pm 34.80$ & $<0.001$ \\
\hline Total kolesterol (mg/dl) & $152.80 \pm 44.46$ & $117.01 \pm 43.89$ & $<0.001$ \\
\hline HOMA-IR & $5.58 \pm 4.74$ & $4.09 \pm 4.95$ & $<0.001$ \\
\hline $\operatorname{AFP}(\mathrm{ng} / \mathrm{ml})$ & $101.02 \pm 190.31$ & $11.51 \pm 22.63$ & $<0.001$ \\
\hline $\mathrm{HBsAG}+(\%)$ & 93.00 & 90.00 & $0.36^{* *}$ \\
\hline HBV-DNA (IU) & $239233.32 \pm 98323.79$ & $150478.78 \pm 75233.89$ & 0.004 \\
\hline
\end{tabular}

ALT: Alanin aminotransferaz; AST: Aspartat aminotransferaz; ALP: Alkalen fosfataz; GGT: Gamma-glutamil transferaz; HOMA-IR: Homeostasis model assesmentInsulin resistance; AFP: Alfa fetoprotein; HBsAG: Hepatit B surface antijeni; HBV-DNA: Hepatit B virüsü deoksiribonükleik asit

*Mann Withney Testi, **Ki-Kare Testi 
Tablo 2. HCC ve non-HCC hastalarının siroz komplikasyonları açısından değerlendirilmesi

\begin{tabular}{lccc} 
& HCC (n=114) & Non-HCC (n=210) & P* \\
\hline Özofagus varis kanaması n (\%) & $20(17,5)$ & $69(32,9)$ & 0,003 \\
\hline Spontan Bakteriyel Peritonit n (\%) & $26(22,8)$ & $22(10,5)$ & 0,003 \\
\hline Hepatik Ensefalopati n (\%) & $20(17,5)$ & $99(47,1)$ & $<0,001$ \\
\hline Asit n (\%) & $46(40,4)$ & $172(81,9)$ & $<0,001$
\end{tabular}

HCC: Hepatosellüler karsinom; *Ki-Kare Testi

Tablo 3. HCC için bağımsız risk faktörlerinin değerlendirilmesi

\begin{tabular}{lccc} 
& Odds Oranı & 95\% Cl & P* \\
\hline Yaş & 0.273 & $0.067-1,109$ & 0.069 \\
\hline Cinsiyet (erkek) & 1.046 & $0.985-1.110$ & 0.144 \\
\hline Beden kitle indeksi $\left(\mathrm{kg} / \mathrm{m}^{2}\right)$ & 1.071 & $0.925-1.240$ & 0.358 \\
\hline ALT (IU/L) & 1.015 & $0.994-1.037$ & 0.171 \\
\hline AST (IU/L) & 0.981 & $0.963-1.000$ & 0.055 \\
\hline ALP (U/L) & 1.009 & $1.003-1.006$ & 0.004 \\
\hline GGT (U/L) & 0.998 & $0.993-1.003$ & 0.334 \\
\hline Total bilüribin (mg/dl) & 0.872 & $0.670-1.136$ & 0.311 \\
\hline Albümin (g/dl) & 3.954 & $1.508-10.368$ & 0.005 \\
\hline Trigliserit (mg/dl) & 1.010 & $0.993-1.027$ & 0.242 \\
\hline Total kolesterol (mg/dl) & 1.007 & $0.992-1.022$ & 0.379 \\
\hline HOMA-IR & 0.999 & $0.914-1.092$ & 0.980 \\
\hline AFP (ng/ml) & 1.017 & $1.011-1.107$ & 0.001 \\
\hline HBV-DNA (IU) & 1.000 & $1.000-1.000$ & 0.037 \\
\hline HBsAG (+) & 0.728 & $0.147-3.611$ & 0.698 \\
\hline
\end{tabular}

ALT: Alanine aminotransferaz; AST: Aspartat aminotransferaz; ALP: Alkaline fosfataz; GGT: Gamma-glutamil transferaz; HOMA-IR: Homeostatic model assessment insulin resistance; AFP: Alfa fetoprotein; HBV-DNA: Hepatit B virüsü deoksiribonükleik asit; HBsAG: Hepatit B yüzey antijeni

*Lojistik regresyon analizi modelinde HCC ile bağımsız risk faktörleri arasındaki ilişkiye bakııdı. HCC'nin varlığına göre değerlendirilme yapıldı.

HCC oluşumunu öngörebilecek bağımsız risk faktörleri incelendiğinde ALP, AFP ve HBV-DNA değerlerinin istatistiksel olarak bağımsız risk faktörü olduğu görüldü (Tablo 3).

\section{TARTIŞMA}

Çalışmamızda HCC olan grupta yaş ortalaması, GGT, albümin, trigliserit, total kolesterol, HOMA-IR, HBV-DNA ve AFP değerleri daha yüksek saptanırken, ALP, AFP ve HBV-DNA'nın da HCC için bağımsız risk faktörü oldukları bulundu. Bu çalışma; HBV'ye bağlı siroz hastalarında HCC ile ilişkili faktörlerin ortaya konması açısından literatüre katkıları olacağından önemli bir çalışmadır.

Dünyada sık görülen, agresif olan HCC kansere bağlı ölümlerin 3. nedenidir (14). HCC'nin etiyolojisine bakıldığında en çok HBV enfeksiyonu suçlanmaktadır $(9,10)$. HBV'nin mikro-RNA ile insan DNA'sına integrasyon yapa- rak, supressor gen mutasyonunu indükleyerek ve hücresel onkogenleri aktive ederek HCC'ye sebep olduğu varsayılmaktadır (15-18) Her ne kadar siroz olmadan da HBV HCC'ye sebep olsa da HCC'nin çoğunluğu sirotik karaciğerden gelişmektedir (19). Sirozlu hastalarda HCC gelişme riski \%3 civarında olup sirozun dekompanse olması bu riski artırımaktadır $(20,21)$. Yapılan çalışmalarda ileri yaş, erkek cinsiyet, obezite, yüksek AFP değeri, sigara, alkol ve siroz gibi birçok etken HCC için prediktif faktörler olarak bulunmasına rağmen, HBV'li siroz hastalarında HCC ile ilişkili faktörler üzerine çalışmalar da devam etmektedir $(6,11-13,22)$. HBV'li siroz hastalarında HBsAg pozitifliği ile veya HBsAg düzeyi ile ve HBV-DNA değeri ile HCC arasında ilişki olduğunu gösteren çalışmalar olsa da $(22,23)$ buna karşın ilişki olmadığını hatta HBsAg ve HBV-DNA'nın azaldığını gösteren çalışmalar da $(12,13)$ mevcuttur. 
Bizim çalışmamızda HBV'ye bağlı siroz hastalarında HCC olan grupta literatürle uyumlu olarak yaş ortalaması, HOMA-IR, HBV-DNA ve AFP değerleri daha yüksek saptandı. Yine literatürle uyumlu olarak BMI, HCC grubunda daha yüksek olmasına rağmen non-HCC grubuna göre istatistiksel olarak anlamlı değildi. Cinsiyet ve HBsAg pozitifliği ise HCC ile non-HCC grubunda benzer bulundu. Aynı zamanda HBV'ye bağlı siroz hastalarında HCC gelişimi için prediktif faktörler incelendiğinde albümin, AFP, ALP ve HBV-DNA bağımsız risk faktörü olarak bulundu. Çalışmalarda erkek cinsiyet HCC için prediktif faktör olarak belirtilmesine rağmen bizde HCC için prediktif faktör olarak saptanmaması hastalarımızın çoğunluğunun erkek olmasından kaynaklanmış olabilir.

Siroz hastalarında siroz süresi ve sirozun dekompanse olmasının HCC gelişme riskini arttırdığı bilinmektedir (21). Bizim çalışmamızda sirozun komplikasyonları incelendi-

\section{KAYNAKLAR}

1. Parkin DM, Bray F, Ferlay J, Pisani P. Global cancer statistics, 2002. CA Cancer J Clin 2005;55:74-108.

2. Chang UK, Kim MS, Han CJ, Lee DH. Clinical result of stereotactic radiosurgery for spinal metastasis from hepatocellular carcinoma: comparison with conventional radiation therapy. J Neurooncol 2014;119:141-8

3. IARC Working Group on the Evaluation of Carcinogenic Risks to Humans. Tobacco smoke and involuntary smoking. IARC Monogr Eval Carcinog Risks Hum 2004;83:1-1438.

4. Yeo Y, Gwack J, Kang S, et al. Viral hepatitis and liver cancer in Korea: an epidemiological perspective. Asian Pac J Cancer Prev 2013;14:6227-31.

5. Simonetti RG, Camma C, Fiorello F, et al. Hepatitis $C$ virus infection as a risk factor for hepatocellular carcinoma in patients with cirrhosis. A case-control study. Ann Intern Med 1992;116:97-102.

6. Fattovich G, Stroffolini T, Zagni I, Donato F. Hepatocellular carcinomain cirrhosis: incidence and risk factors. Gastroenterology 2004; 127:35-50.

7. Lok ASF. Hepatitis B infection: Pathogenesis and management. J Hepatology 2000;32:89-97.

8. Torbenson M, Thomas DL. Occult hepatitis B. Lancet Infect Dis 2002;2:479-86.

9. Perz JF, Armstrong GL, Farrington LA, Hutin YJ, Bell BP. The contributions of hepatitis $B$ virus and hepatitis $C$ virus infections to cirrhosis and primary liver cancer worldwide. J Hepatol 2006;45:529-38.

10. Gurtsevitch VE. Human oncogenic viruses: hepatitis B and hepatitis $C$ viruses and their role in hepatocarcinogenesis. Biochemistry 2008;73:504-13.

11. Chen $X L, X u Y Y$, Chen $L$, Wang $G L$, Shen $Y$. TLR3 plays significant roles against HBV-associated HCC. Gastroenterol Res Pract 2015;2015:572171.

12. Tantiwetrueangdet $A$, Panvichian $R$, Sornmayura $P$, Sueangoen $N$, Leelaudomlipi S. Reduced HBV cccDNA and HBsAg in HBV-associated hepatocellular carcinoma tissues. Med Oncol 2018;35:127. ğinde HCC grubunda non-HCC grubuna göre özofagus varis kanaması, asit ve hepatik ensefalopati daha az görülürken, spontan bakteriyel peritonitin fazla görüldüğü saptandı. Bunda HBV'ye bağlı sirozun ilerleme olmadan da HCC'ye gelişimi ve HCC hastalarının sirozun ileri evrelerine gelmeden kaybedilmesinin rolü olabilir.

Çalışmamızda bazı kısıtlayıcı faktörler de bulunmakta idi. Çalışmamızın retrospektif olması, tek merkezli olması, erkek cinsiyet oranının yüksek olması ve çalışmadaki hasta gruplarının tek etnik kökenden gelen hastalardan oluşturulması çalışmamızın başlıca dezavantajları olarak kabul edilebilir.

Çalışmamızda HBV'ye bağlı siroz hastalarında HCC için AFP ve HBV-DNA değerleri bağımsız risk faktörü olarak saptandı. AFP ve HBV-DNA değerleri HBV'ye bağlı siroz hastalarında HCC için önemli birer belirteç olabilirler.

13. Wei $Y, Y e W$, Zhao $W$. Serum iron levels decreased in patients with HBV-related hepatocellular carcinoma, as a risk factor for the prognosis of HBV-related HCC. Front Physiol 2018;9:66.

14. Ferlay J, Soerjamataram I, Dikshit R, et al. Cancer incidence and mortality worldwide: sources, methods and major patterns in GLOBOCAN 2012. Int J Cancer 2015;136:E359-86.

15. Wang $M, X i D$, Ning Q. Virus-induced hepatocellular carcinoma with special emphasis on HBV. Hepatol Int 2017;11:171-80.

16. Daud M, Rana MA, Husnain T, ljaz B. Modulation of Wnt signaling pathway by hepatitis B virus. Arch Virol 2017;162:2937-47.

17. Gao J, Xiong $Y$, Wang $Y$, et al. Hepatitis $B$ virus $X$ protein activates Notch signaling by its effects on Notch 1 and Notch4 in human hepatocellular carcinoma. Int J Oncol 2016;48:329-37.

18. Yoneda M, Hyun J, Jakubski S, et al. Hepatitis B Virus and DNA Stimulation Trigger a Rapid Innate Immune Response through NFкB. J Immunol 2016;197:630-43.

19. Yang JD, Kim WR, Coelho R, et al. Cirrhosis is present in most patients with hepatitis B and hepatocellular carcinoma. Clin Gastroenterol Hepatol 2011;9:64-70.

20. Tsukuma H, Hiyama T, Tanaka S, et al. Risk factors for hepatocellular carcinoma among patients with chronic liver disease. N Engl J Med 1993; 328:1797-801.

21. Colombo $M$, de Franchis $R$, Del Ninno $E$, et al. Hepatocellular carcinoma in Italian patients with cirrhosis. N Engl J Med 1991;325:67580.

22. Hoshida Y. Risk of recurrence in hepatitis B-related hepatocellular carcinoma: impact of viral load in late recurrence. J Hepatol 2009;51:842-44.

23. Beasley RP, Hwang LY, Lin CC, Chien CS. Hepatocellular carcinoma and hepatitis B virus. A prospective study of 22,707 men in Taiwan. Lancet 1981;2:1129-33. 